\title{
Erratum to: Effects of angled-impeller rotational speed and aeration rate on production of artemisinin and cell biomass of Artemisia annua L.
}

\author{
King Wey Heng ${ }^{1}$ - Derek Juinn Chieh Chan ${ }^{2}$ - Lai Keng Chan ${ }^{1}$
}

Published online: 17 December 2015

(C) The Society for In Vitro Biology 2015

\section{Erratum to: In Vitro Cell.Dev.Biol.-Plant (2015) 51:324-331 DOI 10.1007/s11627-015-9678-9}

The following paragraph needs to be added in the Materials and methods section:

Determination of artemisinin content. Approximately $0.5 \mathrm{~g}$ of dried powdered cells were weighed and ultra sonicated in $3 \mathrm{ml}$-hexane (Merck, USA) at $40^{\circ} \mathrm{C}$ for $90 \mathrm{~min}$. The supernatant of the hexane extract was collected in a test tube followed by the addition of $3 \mathrm{ml}$ of fresh $\mathrm{n}$-hexane to dried cells every $30 \mathrm{~min}$. This process was repeated 3 times. The hexane extract was then evaporated to dryness and reconstituted with approximately $0.5 \mathrm{ml}$ of acetonitrile HPLC grade (Merck,
USA). Filtration of the hexane extract with $0.45 \mu \mathrm{m}$ Milipore was conducted before transferring into vials for HPLC analysis. The determination of artemisinin content was carried out using HPLC-UV at $210 \mathrm{~nm}$ with a LiChrospher ${ }^{\circledR}$ RP-18100 column of $4 \times 250 \mathrm{~mm}$ at a flow rate of $0.3 \mathrm{ml} \mathrm{min}^{-1}$. The mobile phase consisted of an isocratic mixture of acetonitrile:water mobile phase buffer (65:35). Pure artemisinin 98\% (Sigma-Aldrich, USA) standards were used with concentration range of $31.25-500 \mathrm{~g} \mathrm{~mL}^{-1}$ per $20 \mu \mathrm{L}$ injection volume.

The last line of Table 6 should be corrected as follows:

$\mathrm{g} / \mathrm{g}$ dried cell mass $\rightarrow \mu \mathrm{g} / \mathrm{g}$ dried cell mass

The online version of the original article can be found at http://dx.doi.org/ 10.1007/s11627-015-9678-9.

Lai Keng Chan

1kchan@usm.my

School of Biological Sciences, Universiti Sains Malaysia, 11800, Minden Pulau Pinang, Malaysia

2 School of Chemical Engineering, Engineering Campus, Universiti Sains Malaysia, Seberang Perai Selatan, 14300, Nibong Tebal Pulau Pinang, Malaysia 